\title{
Words about God in the peripheral communities of Medellín
}

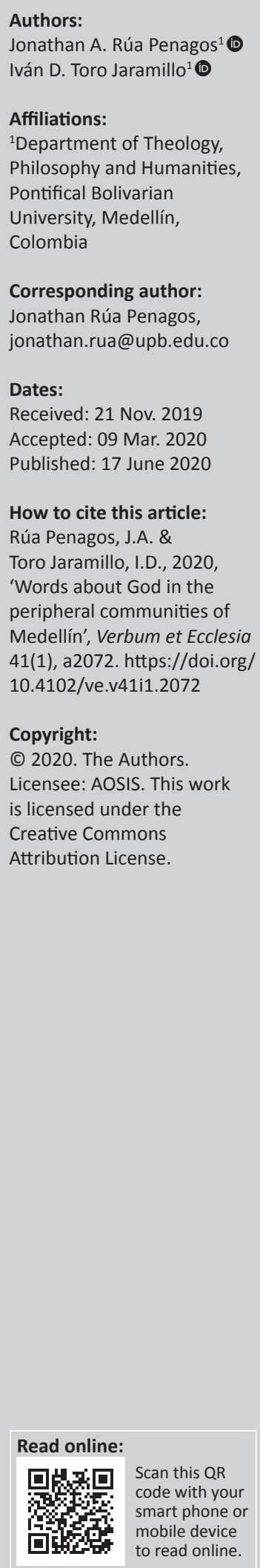

This article aims to analyse the 'words about God' in the five peripheral ecclesiastic communities of Medellín by using a hermeneutic and ethnographic method. The analysis comprises two phases: firstly, the population subject and object of study are characterised; secondly, the views and attributes of God that the subjects acquire from the religious experience are identified. It is concluded that most of the individuals involved in the study assume the existence of God, who is perceived as being personal, eternal, spiritual and supreme. The influence of a Trinitarian view of deity, which implies an act of trust, is evidenced in their statements. In this context, God is, above all, powerful: he acts and creates. In the subjects' demonstration of their experiences, there are no conceptual differences in relation to how Christianity sees God. Although traditional languages are used to refer to the contents of their faith, the manner in which each aspect is understood and explained is not uncomplicated. This has an effect on ecclesiastic practices.

Intradisciplinary and/or interdisciplinary implications: The outcome of this research project sets a relation amongst ecclesiology, pastoral and both systematic and contextual theology; it also establishes a dialogue where the actors of social and human science, such as the anthropology, feel identified in terms of the use of categories, techniques and data collection research instruments.

Keywords: God; creed; ecclesiastic communities; poverty; Medellín.

\section{Introduction}

Latin America is a multi-cultural and ethnic territory, characterised by a strong religious experience. In the midst of the secularisation processes that some Latin American countries are conducting, a continuous interest in the different ways of life for the purpose of achieving transcendence is evidenced, even for institutionalised lifestyles (Conselho Episcopal LatinoAmericano 2007). This is the case of Medellín, Colombia, where legitimate and internalised efforts to achieve evangelical authenticity exist at a cultural level. Medellín remains a city with inhabitants that live the Christian experience.

Medellín is an example for Latin America in terms of anthropological, theological and ecclesiastic matters. The number of believers that practise Christianity from the Catholic tradition is considerable. This is reflected in the number of baptised individuals and callings for consecrated, canonically speaking and clerical states of life. Furthermore, the Second General Conference of Latin America and the Caribbean Episcopate of 1968 held in this city embraced the words of the Second Vatican Council and encouraged new methods of preaching the gospel, particularly in the context of the poverty and exclusion present across the continent.

In relation to the aforementioned, there is an issue that reaches an epistemological and pedagogical dimension that is related to the manner in which language is used and the comprehension of the contents of faith of these Catholics and to the relationship that these expressions have with theological and ecclesiastic tradition. The assessment of popular constructions on religious matters remains unclear; similarly, the popular religiousness and the ways to comprehend both what is believed and how it is believed have yet to be ascertained. Such diverse and valuable experiences are often discredited because of their lack of scientific rigour or heterodoxy in practising faith.

Therefore, the following research question is suggested: which are the words about God, from the religious experience, in some of the peripheral ecclesiastic communities of Medellín? Specifically, how are these peripheral ecclesiastic communities of Medellín characterised? Moreover, how is 
the first article of Christian faith comprehended by them? From these questions, it is subsequently expected that the general objective of this study will be fulfilled, that is, an analysis of the 'words about God' in the peripheral ecclesiastic communities of Medellín through a hermeneutic and ethnographic method so as to understand Christian faith and the popular experience on religious matters. To conduct the research, some peripheral ecclesiastic communities of Medellín will be characterised, thereby contextualising people's words and the way in which the said context affects their viewpoints regarding the world and God. Furthermore, the different methods of comprehending the first article of the Christian faith in these territories will be clarified.

\section{Theoretical framework}

\section{The concept of God}

Typically, God is understood as 'to where' human beings are headed for - a reality that supports what exists and enables human beings to live and love radically (Rahner 1979) and as a possibility for personal and communitarian awareness, plenitude and realisation. Currently, several studies address the concept of God (De Lecaros 2017; Jensen 2018; Younger 2018), taking the image that people may have of him into account. Different areas of knowledge, such as theology, philosophy, anthropology and history, have even considered what this reality entails and possible methods for understanding it (Lane 2018; Luciani 2017; Turpe Chaparro 2017; Uwineza 2018). These areas do not necessarily evidence such images through ethnographic studies in popular contexts.

For its part, the Dogmatic Constitution Dei Verbum (n.2) explains how the Magisterium understands transcendence with its tradition:

In His goodness and wisdom, God chose to reveal Himself and to make known to us the hidden purpose of His will by which, through Christ, the Word made flesh, man might in the Holy Spirit have access to the Father and come to share in the divine nature. (n.p.)

This reflects a Trinitarian context typical of Christianity and the manner in which such a tradition formulates the contents of its faith.

\section{Popular hermeneutics, Sensus fidei fidelis and Sensus fidei fidelium}

Hermeneutics is related to an individual's potential to understand the world (Gadamer 2004; Heidegger 2009). Popular hermeneutics indicate that the construction of knowledge employs the interpretation of a people's experience as a starting point, which - for the purposes of this research - are the experiences of the peripheral communities of Medellín (Orofino \& Mesters 2007). The popular reading of the Bible, for example, is an important background in this type of work, because it constitutes the community's interpretation from their knowledge of the events, difficulties and problems that affect them on a day-today basis. The word allows individuals to sense liberating elements to improve the relations of justice and common good in different contexts. Popular hermeneutics allows the concrete and historical ways in which God has saved humanity to be recognised.

Recently, the International Theological Commission addressed the topic of Sensus fidei fidelis and Sensus fidei fidelium, specifically, in the documents Teologia hoje: perspectivas princípios e criterios (Comissão Teológica Internacional 2012) and O Sensus fidei na vida da Igreja (Comissão Teológica Internacional 2014). These documents address an aspect the problem investigated in this study, which is related to developing the communities' experiences of faith into the main topic of discussion. This accounts for popular hermeneutics in that the community, through its experience, interprets God's manifestation in their lives and that these experiences have become the main topic of discussion by the Magisterium and family traditions in a particular manner.

At this stage, it is important to consider the difference between Sensus fidei fidelis, which refers to the capacity of an individual to discern matters of faith, and Sensus fidei fidelium, which is related to what the Church considers a community. This study examines these two concepts in relation to the first article of the Christian faith.

\section{The contextual component}

If our interest is related to the contents of dogmatism, upon dealing with the first article of faith, the contextual component is not excluded from this reflection, because the starting point of theology is specific. According to this, God's self-manifestation to men as the first moment of the history of salvation cannot be denied (Waldenfels 1994).

A context reflects the historical, social, cultural, political, economic and religious reality of a person. The contexts in which theological knowledge is built are multiple, varied and diverse, for example, drug addiction, organisations, family, health, displaced people, poverty, virtuality, indigenous peoples, conflicts, sports, politics, economy, environment, law and a sense of meaninglessness of current humanity, amongst others.

If theology seeks to be believable, it should not lose focus of the specific problems of humanity (Parra 2003). Therefore, to apply dogmatic theology, it is necessary to contextualise theology based on popular hermeneutics. This implies that the main agents of the research agenda are the people living in the communities, because they are the ones who would give their views of the world, society and God. Consequently, contextualised theology would allow believers to become closer to God so as to directly affect their lives.

\section{Peripheral ecclesiastic communities of Medellín}

Recently, Pope Francis in his papal bull Misericordiae Vultus (2015b) mentioned a category being widely used by the ecclesiastic and theological community: the concept 
TABLE 1: Research sample.

\begin{tabular}{llcll}
\hline ID & Municipality & Multidimensional Poverty Index & Peripheral ecclesiastic community & Supporting educational institution \\
\hline 1 & Popular & 33.97 & La Pasión de Nuestro Señor Jesucristo & Not applicable \\
2 & Santa Cruz & 36.6 & María Rosa Mística & República de Honduras \\
3 & Manrique & 37.28 & San Lorenzo Mártir & Gente Unida \\
8 & Villa Hermosa & 38.41 & Santa María de la Sierra & La Sierra \\
90 & Santa Elena & 39.5 & Santa Elena & Santa Elena \\
\hline
\end{tabular}

ID, identification.

of 'periphery'. The Pope referred to existential periphery, involving situations of scarcity and suffering. According to the Pope, those who suffer this calamity have been silenced by societies that have higher standards of living.

The concept of peripheral areas is closely related to that of poverty, which is a category widely explored in the Latin American theology tradition (Gutiérrez 2000). In the Laudato $\mathrm{Si}^{\prime}$ (Francis 2015a) circular, the Pope describes what he understands as being poor in precise terms. Generally, a poor person is an individual who has nothing, namely, a deprived and excluded person. In addition, people of poverty and those without adequate accommodation are the ones crucified in the history of humanity, a state that is created by the inequity of the world. Although the concept of poverty is wider, the Pope specifically uses the term in the material sense, that is, a poor person is someone who has hunger for bread and God.

In Colombia, there are several standards for measuring poverty and extreme poverty, such as the Gini Index, the Human Development Index and the Multidimensional Poverty Index. The latter allows one to identify the poorest municipalities located in the peripheral area. In relation to the peripheral ecclesiastic communities of Medellín, we are considering the parochial communities with the highest Multidimensional Poverty Index, that is, the communities that have been systematically impoverished in the city (Alcaldía de Medellín 2017).

\section{Methods}

This study follows a historical-hermeneutic approach (Cifuentes Gil 2011), because it is constructed within the context of an interpretative paradigm, that is, an understanding of the world and its events, and a qualitative approach, because the analysis of data is not strictly numerical or statistical (Ramos 2015). The hermeneutic method was used to build knowledge (Gadamer 2004; Heidegger 2009) resulting from the interpretation abilities of the subjects, particularly of those living in popular or peripheral contexts. Furthermore, the ethnographic method was used (Guber 2011), where the research involves examining social events from the point of view of people who experience the reality under investigation through fieldwork. Research techniques such as surveys, interviews and focus groups (FG) were developed. The five municipalities with the highest Multidimensional Poverty Index in Medellín ${ }^{1}$ were selected for the fieldwork, as shown in Table 1. 1.In this sample, San Sebastián de Palmitas, which ranks fifth in the table, is not
included because the ecclesiastic communities in this part of the territory do not belong to the Archdiocese of Medellín.
A peripheral ecclesiastic community and an educational institution to support the research process were identified in each territory so as to evidence some form of cohesion amongst the subjects. Generally, such characteristics are developed by the Church and the school as structures with communitarian features. Subsequently, the communities and institutions were visited to account for the context, instruments such as the focus group and interview were designed to collect information and the forms for the survey were distributed. In total, 52 adults who had children and were a part of the area's educational processes participated in the Survey. These inclusion criteria allowed relationships between the Church and the school to be established in relation to education.

The organisation, analysis and systematisation of the data were conducted by using the Nvivo (Version 12) research software. A codification process of the FG and interviews was carried out for a subsequent theoretical construction and exhibition of the results obtained from these procedures (Cáceres 2003).

\section{Ethical considerations}

This article followed all ethical standards for a research without direct contact with human or animal subjects.

\section{Results Characterisation}

Knowledge is built in a particular context. Human beings speak based on the place where they live, their customs, experiences, habits and traditions. The characterisation of the population of study is useful because it enables the researcher to perform a located analysis of information, understand and interpret the actions, ideas and feelings of the community in a more accurate manner compared to how they have been expressed. A study of data without prior context would entail the risk of misinterpreting what the communities live through on a daily basis. Thus, some data that allow researchers and readers to comprehend how people live in the peripheral area of Medellín are initially presented.

\section{Context}

Three of the five municipalities with the highest Multidimensional Poverty Index in Medellín are located in the north-eastern area of the city: Popular, Santa Cruz and Manrique. The remaining two municipalities are in the following locations: one is in the centre eastern area of the city, Villa Hermosa; the other one is a village in a rural area, Santa Elena. All these locations share some characteristics that allow the people living in the areas to have several 
opportunities for further development. However, at the same time, certain situations that put their lives into permanent risk are also present.

In terms of safety, a safe environment is perceived; walking through the neighbourhoods without any difficulty or fear is possible. Former violence is no longer an element featuring in these areas, although some are stigmatised by their history, such as Manrique and La Sierra (Villa Hermosa). Peace and reconciliation processes between violent actors have penetrated the communities' conscience, and people live in a quiet and relatively safe environment. Although safety perception is important, inhabitants complain, generally, about the use of psychoactive substances in public places, which may affect the quality of life of their children.

These territories live in a context of poverty and hunger, as stated by an interviewee: 'in all the neighbourhoods of Medellín and Colombia, there are a lot of poor people' (Focus group 2). This reality is not only evidenced in the material scarcity of people but also in the structures of injustice and corruption mentioned in their stories. On several occasions, the government's involvement is present because of electionrelated interests: there are 'lots of benefits, but only during periods of campaign, once the election passes, there is no health [plan solution], nothing' (Focus group 1).

Typically, families living in these territories comprise people from other places of Antioquia or Colombia, who had to leave their lands because of forced displacement to seek opportunities. Thus, these people have established themselves in the peripheral areas of Medellín. The families attempt to strengthen the relationships amongst family members, which are often questioned in their homes: 'I see some flaws in the questioning on children's education at home' (Focus group 2).

There is a wide variety of educational programmes, namely, there are public as well as private institutions that educate citizens in a comprehensive manner. Thus, improving the quality of and processes followed by school staff is of vital importance. In this regard, the following is stated in an FG: 'more rigorousness is required regarding education' (Focus group 1). In some cases, families cover long distances for their children's education despite continuous complaints related to flaws in the educational system.

In relation to health, the outlook is not promising. In most statements, a generalised complaint arising from the poor functioning of the services is evident. Access, assistance and the perception of a comprehensive service are not positively assessed by the inhabitants of these municipalities in the city.

Some areas are farther away from the city centre, such as La Honda (Manrique), La Sierra (Villa Hermosa) and Santa Elena, making mobility difficult. Modes of transport have improved because of the Comprehensive Public Transport System of Medellín. However, the community is still unsatisfied when it comes to access routes and flexibility in the service.
The options available for physical, entertaining and leisure activities could be improved in some areas. Gradually, cultural dynamics are becoming a possible aspect for the development of these communities. Nevertheless, the presence of the state is necessary to strengthen the gaps that have been traditionally left pending.

In terms of religion, there is an ecclesiastic structure that is focused primarily on spiritual and pastoral matters. This structure serves as a bridge between communitarian processes and state proposals. The community's involvement in these spaces as well as communication needs to be strengthened to achieve a wider dissemination of religious projects. The presence of other religious and ecclesiastic movements can be noted in these municipalities.

\section{Age, gender and marital status}

Most interviewees were women aged 31-50 years old and were either married or living under the Common Law marriage. Table 2 shows a higher tendency of this sector of the population to participate in communitarian and religious processes. However, despite having a high percentage, the sacrament of matrimony is not a common practice in families living in the peripheral areas of Medellín.

\section{Municipality and the social stratum}

It is evident from Table 3 that most of the population of the sample occupied the low social strata, with stratum 1 being the prevailing one. Living in a territory with such characteristics decreases the family support expenses, which are related to household payments, food, transport, education, leisure activities and public services, amongst others. People who were placed in stratum 3 live in Santa

TABLE 2: Age, gender and marital status.

\begin{tabular}{lccc}
\hline Age and marital status & \multicolumn{2}{c}{ Gender } & \multirow{2}{*}{ Total (\%) } \\
\cline { 2 - 3 } & Female (\%) & Male (\%) & \\
\cline { 2 - 3 } 21-30 years old & $\mathbf{2 7}$ & $\mathbf{4}$ & $\mathbf{3 1}$ \\
Married & 4 & 0 & 4 \\
DK/NA & 4 & 0 & 4 \\
Single & 10 & 2 & 12 \\
Common Law Marriage & 10 & 2 & 12 \\
31-50 years old & $\mathbf{4 8}$ & $\mathbf{4}$ & $\mathbf{5 2}$ \\
Married & 10 & 0 & 10 \\
DK/NA & 4 & 0 & 4 \\
Separated & 6 & 0 & 6 \\
Single & 13 & 2 & 15 \\
Common Law Marriage & 15 & 2 & 17 \\
51 years old or older & $\mathbf{1 3}$ & $\mathbf{2}$ & $\mathbf{1 5}$ \\
Married & 4 & 2 & 6 \\
DK/NA & 2 & 0 & 2 \\
Separated & 2 & 0 & 2 \\
Common Law Marriage & 2 & 0 & 2 \\
Widow or Widower & 4 & 0 & 4 \\
DK/NA & $\mathbf{2}$ & $\mathbf{0}$ & $\mathbf{2}$ \\
DK/NA & 2 & 0 & 2 \\
\hline Total & $\mathbf{9 0}$ & $\mathbf{1 0}$ & $\mathbf{1 0 0}$ \\
\hline
\end{tabular}

Note: Data in bold corresponds to age ranges. DK/NA, Don't Know or no answer. 
Elena's village. This is likely because of the migration of many middle-class people to a rural area because of their desire for a natural space away from the city centre.

\section{Level of education and profession or trade}

Most interviewees had a secondary school diploma or some level of education, as shown in Table 4. Illiteracy has significantly decreased in this area because of an increase in the availability of educational programmes. Technological or university-level education is scarce. In relation to higher education, there is a preference for trade training, that is, technical education, primarily because the peripheral areas have no higher education institutions.

Another aspect worth mentioning is related to the substantial amount of people doing housework; few people have a formal job or are currently studying. In this culture, the most common feature is for women to stay at home to take care of the children and the housework while men work to provide for the family's resources and food needs.

\section{Institutions and grades attended by children}

The children of most of the family men who participated in this study were in lower grades, as shown in Table 5. It is likely that these men participated in the research project because it is more common for adults to accompany children at these ages to provide them with care and attention.

As previously stated, there are several educational programmes in the peripheral sectors. One of the main difficulties in these areas is not regarding access to education but rather regarding the decision to go to school. It is also important to determine the extent to which graduates of

TABLE 3: Municipality and social stratum.

\begin{tabular}{|c|c|c|c|c|c|c|}
\hline \multirow[t]{2}{*}{ Municipality } & \multicolumn{5}{|c|}{ Social stratum (\%) } & \multirow[t]{2}{*}{ Total (\%) } \\
\hline & 0 & 1 & 2 & 3 & DK/NA & \\
\hline 1 Popular & 0 & 10 & 6 & 0 & 0 & 15 \\
\hline 2 Santa Cruz & 2 & 2 & 17 & 0 & 6 & 27 \\
\hline 3 Manrique & 2 & 29 & 2 & 0 & 4 & 37 \\
\hline 8 Villa Hermosa & 0 & 6 & 0 & 0 & 0 & 6 \\
\hline 90 Santa Elena & 0 & 4 & 6 & 6 & 0 & 15 \\
\hline Total & 4 & 50 & 31 & 6 & 10 & 100 \\
\hline
\end{tabular}

DK/NA, don't know or no answer. these institutions have genuine opportunities to enter into the labour market or university life.

The above results show that the peripheral ecclesiastic communities of Medellín that participated in this study are characterised by living in a context of poverty and far from the city centre. Most are adult women who send their children to school, who are involved in housework and in their children's education. These women's level of education is basic, and only a few attend higher education institutions. This population lives a unique experience with respect to faith and interprets faith from said experience. Somehow, their vision of God is determined by or, rather, told from their context.

\section{Words about God}

\section{God exists}

Most of the population stated that God exists, as shown in Table 6. This conviction was provided through various factors such as family influence, an act of faith related to the creation of everything that exists, the different manifestations of the deity or even, as stated by one participant, health in times of sickness:

'Science progresses and one expects much more from doctors, but I stick to God and, by sticking to Him, I saw that He exists because my daughter got cured. From that day on, I said: God does exist'. (Focus group 1)

Only $2 \%$ of participants claimed not to believe in God. The ecclesiastic community is an open space that embraces individuals who practise different creeds and have different professions, which allows for the aforementioned percentage. These people participated because of a particular reason; in this case, the reason is related to their children's education in terms of rules and regulations or for the purposes of providing their children with protective factors against contextual risks.

\section{God as a personal, eternal, spiritual and supreme being}

Who is God? When faced with this question, most people associated the concept with a personal, eternal and spiritual being or with a supreme reality; somehow, a metaphysical view prevailed, as shown in Table 7 . In addition, a high percentage of the participants imagined God as a tangible,

TABLE 4: Level of education and profession or trade.

\begin{tabular}{|c|c|c|c|c|c|c|}
\hline \multirow[t]{2}{*}{ Level of education } & \multicolumn{5}{|c|}{ Profession or trade } & \multirow[t]{2}{*}{ Total (\%) } \\
\hline & Employee (\%) & Student (\%) & DK/NA (\%) & Housework (\%) & Informal employee (\%) & \\
\hline DK/NA & 2 & 0 & 0 & 2 & 2 & 6 \\
\hline Primary completed & 0 & 0 & 0 & 13 & 2 & 15 \\
\hline Primary incomplete & 2 & 0 & 2 & 2 & 2 & 8 \\
\hline Secondary completed & 6 & 2 & 8 & 21 & 4 & 40 \\
\hline Secondary incomplete & 0 & 2 & 2 & 4 & 2 & 10 \\
\hline Technologist & 0 & 2 & 0 & 0 & 0 & 2 \\
\hline University & 2 & 0 & 0 & 2 & 0 & 4 \\
\hline Total & 17 & 8 & 13 & 50 & 12 & 100 \\
\hline
\end{tabular}

DK/NA, don't know or no answer. 
TABLE 5: Institutions and grades attended by children

\begin{tabular}{|c|c|c|c|c|c|c|c|c|c|c|c|c|c|}
\hline \multirow[t]{2}{*}{ Institution } & \multicolumn{12}{|c|}{ Grade (\%) } & \multirow[t]{2}{*}{ Total (\%) } \\
\hline & 0 & 1 & 2 & 3 & 4 & 5 & 6 & 7 & 8 & 9 & 11 & DK/NA & \\
\hline Buen Comienzo & 6 & 0 & 0 & 0 & 0 & 0 & 0 & 0 & 0 & 0 & 0 & 0 & 6 \\
\hline Barrio Santa Cruz & 0 & 0 & 0 & 0 & 0 & 0 & 0 & 0 & 2 & 0 & 0 & 0 & 2 \\
\hline El Cerro & 0 & 0 & 2 & 0 & 0 & 0 & 0 & 0 & 0 & 0 & 0 & 0 & 2 \\
\hline El Placer & 0 & 0 & 4 & 0 & 0 & 0 & 0 & 0 & 0 & 0 & 0 & 0 & 4 \\
\hline Fe y Alegría & 0 & 4 & 0 & 0 & 2 & 0 & 0 & 0 & 0 & 0 & 0 & 0 & 6 \\
\hline Gente Unida & 2 & 4 & 4 & 6 & 6 & 6 & 0 & 0 & 0 & 0 & 6 & 0 & 33 \\
\hline Juan Andrés Patiño & 0 & 2 & 2 & 0 & 0 & 0 & 0 & 0 & 0 & 0 & 0 & 0 & 4 \\
\hline Juan de Dios & 0 & 0 & 0 & 0 & 0 & 2 & 0 & 0 & 0 & 0 & 0 & 0 & 2 \\
\hline La Sierra & 0 & 0 & 0 & 2 & 0 & 0 & 0 & 0 & 0 & 0 & 4 & 0 & 6 \\
\hline Nuevo Horizonte & 2 & 0 & 0 & 0 & 0 & 0 & 2 & 0 & 0 & 0 & 0 & 0 & 4 \\
\hline Pablo Neruda & 0 & 0 & 2 & 0 & 0 & 2 & 0 & 2 & 0 & 0 & 0 & 0 & 6 \\
\hline República de Honduras & 4 & 0 & 0 & 2 & 8 & 0 & 0 & 0 & 0 & 2 & 0 & 0 & 15 \\
\hline Santa Elena & 0 & 0 & 2 & 0 & 0 & 0 & 0 & 2 & 2 & 0 & 0 & 0 & 6 \\
\hline DK/NA & 0 & 0 & 0 & 0 & 0 & 0 & 0 & 0 & 0 & 0 & 0 & 2 & 2 \\
\hline Total & 13 & 10 & 15 & 10 & 15 & 10 & 2 & 6 & 4 & 4 & 10 & 2 & 100 \\
\hline
\end{tabular}

DK/NA, don't know or no answer.

TABLE 6: Existence of God.

\begin{tabular}{lc}
\hline Answer & Participants (\%) \\
\hline No & 2 \\
DK/NA & 2 \\
Yes & 96 \\
\hline Total & $\mathbf{1 0 0}$ \\
\hline
\end{tabular}

DK/NA, don't know or no answer.

TABLE 7: Concept of God.

\begin{tabular}{lc}
\hline Answers & Participants (\%) \\
\hline God is everything & 6 \\
God forgives, he is everything & 2 \\
The reality that men radically face & 4 \\
The deepest reality of human beings & 6 \\
The greatest & 2 \\
Omnipotent creator of existence & 2 \\
A book of rules & 2 \\
A personal, eternal and spiritual being & 37 \\
A being that cannot be known & 8 \\
A supreme being that is love & 2 \\
A person that you can find in heaven and that sees everything & 12 \\
A supreme, absolute and founding reality & 19 \\
\hline Total & 100 \\
\hline
\end{tabular}

sensitive or material person. During the interviews, particular images of God related to affective bonds were highlighted: God as father, friend or teacher.

When asking about the concept of God, some doubt or confusion could be perceived in some participants, who stated that they did not know what they should refer to when speaking about this reality. Conversely, others defined God as a reality that has different names, depending on the religion being practied or as a subjective dimension: 'it is something, something internal, something spiritual, something that one [...]; I believe that we all should know or have someone to believe in; I believe in God' (Interview 1).

Notably, $8 \%$ of the participants claimed that God cannot be known. During the interviews, two tendencies were found in
TABLE 8: View of God.

\begin{tabular}{lc}
\hline Answers & Participants (\%) \\
\hline God is love and he manifests through his son, Jesus Christ & 29 \\
God is Father, Son and Holy Spirit & 56 \\
God speaks, gets angry, acts, rewards and punishes & 8 \\
God does not exist & 2 \\
God is a person and he is merciful & 2 \\
DK/NA & 2 \\
All of the above & 2 \\
\hline Total & 100 \\
\hline
\end{tabular}

DK/NA, don't know or no answer.

the answers: some people claimed that God cannot be known, whereas others claimed that this is possible either at the moment of our death or 'through many people or through things' (Interview 1) or in his second arrival (Focus group 3).

\section{Trinitarian view of God}

In the communities, a Trinitarian view of God prevailed, as shown in Table 8; this view is a fundamental doctrinal element for the Judeo-Christian tradition. God 'is Father, Son and Holy Spirit' (Focus group 2), claimed a participant of the FG. Additionally, there is an evangelical idea that emphasises the Jesus of Nazareth's person and the love expressed by God through his son. Furthermore, the surveys showed that there are still traces of the Old Testament God, who personifies human qualities and is presented in the Bible.

\section{Believing in God as an act of trust}

Most participants defined the act of believing as trust, adhesion or devotion, as shown in Table 9. In other words, the relationship between human beings and God takes place at an existential and everyday level, which is not necessarily related to intellectual matters. Although believing as 'something that is believed about God' ranks third in terms of preferred answers, it is not an option that involves making a difference in people's lives, whose realities are, in many 
TABLE 9: Concept of belief.

\begin{tabular}{lc}
\hline Answers & Participants (\%) \\
\hline Adhere or devote oneself to him & 25 \\
Something believed about God & 4 \\
Trust in him & 60 \\
God is life & 2 \\
Rules or regulations & 2 \\
DK/NA & 2 \\
Have faith and accept his will & 2 \\
A belief & 2 \\
Live like him and for him & 2 \\
\hline Total & $\mathbf{1 0 0}$ \\
\hline
\end{tabular}

DK/NA, don't know or no answer.

TABLE 10: Qualities or attributes of God.

\begin{tabular}{lc}
\hline Answers & Participants (\%) \\
\hline God acts and manifests his will in history & 8 \\
God is kindness, good & 2 \\
God is charity & 2 \\
God is creator & 17 \\
God is almighty & 54 \\
God reigns & 6 \\
God reveals himself & 4 \\
DK/NA & 8 \\
\hline Total & $\mathbf{1 0 0}$ \\
\hline
\end{tabular}

DK/NA, don't know or no answer.

cases, limited. Thus, a cognitive option should not necessarily have an effect on its transcendence.

\section{Qualities or attributes of God}

The three qualities of God favoured by the participants are related to his power, ability to create and act, as shown in Table 10. The concepts of reigning or revelation were not highly prioritised amongst the participants' choices. The FG showed how communities consider God to be present everywhere (omnipresence), how he can be trusted and because he cares, protects and helps, he is an innovative being. His presence is related to states and values such as hope, light, peace, nobility, simplicity, salvation, mercy and tolerance. In a participant's words, God 'to me is love, peace, kindness, glory' (Focus group 3).

\section{God is father, creator and almighty}

There is evidence regarding the influence of the Apostles' Creed in the lives of people. When asking people about their views related to God as father, creator or almighty, the following results can be observed

Fatherhood is inherent to God, which is presented in terms of closeness and fidelity, as shown in Table 11. Although the role of father has been culturally assigned, for participants, the role is more related to the attitudes of deity rather than to blood ties: namely, being father is one of God's roles. The interviews described how God is Father, because he is Jesus' father, as well as how that relationship is extended to all of humanity: God is 'the father that is always aware of what their children are doing' (Interview 1).

With respect to the act of creating, the participants showed a tendency to understand this principle as the manner in which
TABLE 11: God as father.

\begin{tabular}{lc}
\hline Answers & Participants (\%) \\
\hline God is creator & 4 \\
DK/NA & 2 \\
That God is close, faithful and the creator & 87 \\
That God is literally as a father, a member of the family & 8 \\
\hline Total & $\mathbf{1 0 0}$ \\
\hline
\end{tabular}

DK/NA, don't know or no answer.

TABLE 12: Meaning of the act of creating.

\begin{tabular}{lc}
\hline Answers & $\begin{array}{c}\text { Participants } \\
\text { (\%) }\end{array}$ \\
\hline God creates through his wisdom & 4 \\
God created everything according to his perfection & 2 \\
God gives life & 2 \\
God is Father & 2 \\
God has the power & 2 \\
DK/NA & 4 \\
That God literally creates things with his own hands, just as we create & 31 \\
objects & \\
That he is closely related to everything that exists and supports it & 54 \\
\hline Total & $\mathbf{1 0 0}$ \\
\hline
\end{tabular}

DK/NA, don't know or no answer.

God supports the world and everything living in it, as shown in Table 12. However, the second most popular opinion involved the idea of creationism, understood in its literal sense. This opinion is strengthened by the FG through the following statement by one participant:

'When He began to create the world, one day He created something, the next day another thing. He created men, Eva; He saw that all that was good and He began to create all that'. (Focus group 3)

The influence of the Bible in the community's beliefs is apparent, in that a literal reading is made, at least regarding this aspect.

The surveys' results did not favour a view of the power of God in relation to power, control or strength, as shown in Table 13. Instead, the results tend to show that the power of God lies in the fact that he is the origin of the earth processes. According to this, the FG indicated a view of power not as the origin of the world but as God's potential to do what he wants when he wants, as stated by a participant:

'Well [...], if He had the power to do all [...] all that we can see and even what we cannot see is because He is Almighty; He can do anything'. (Focus group 1)

\section{Discussion}

\section{The poor as the subject and object of theological and pastoral research}

Traditionally, theology performs a documentary analysis for hermeneutic studies, which allows understanding the content of faith according to the origins of the belief itself. Dogmatic theology, using a regressive and systematic method, for example, enables one to address the topic of God as an object of knowledge. Thus, it becomes possible to think of the Christian life in a limited context with such a research 
TABLE 13: The power of God.

\begin{tabular}{lc}
\hline Answers & Participants (\%) \\
\hline God is love & 2 \\
God is free & 2 \\
God is everything and gives free will & 2 \\
DK/NA & 2 \\
That God is the author of all processes in the world & 63 \\
That God is able to control and impose his will & 27 \\
If we believe and have faith, everything is possible & 2 \\
\hline Total & 100 \\
\hline
\end{tabular}

DK/NA, don't know or no answer.

methodology (Müller 1998). This study serves as evidence for results that, from the theoretical point of view, enlighten the ecclesiastic and theological reality.

Recently, owing to the epistemological and methodological strengthening of social and human sciences today, new and creative methods of addressing the objects of study have been formulated. In an exercise of interdisciplinary nature, theology has learnt to interact with methodological mediations and theoretical constructions different from the classical ones, namely, philosophy. Thus, socio-analytic mediation appears to systematise data different from data provided through documents. Consequently, the approach to communities is developed based on techniques such as surveys, interviews, FGs, etc.

Addressing the peripheral ecclesiastic communities of Medellín has represented a challenge to theology. Considering the communities' opinions and showing the manner in which they perceive God is a starting point to build further knowledge, which is shaped by data collected through techniques typical of ethnographic methods, such as the survey, interview and the FG. Allowing the communities' intervention through socio-analytic mediation is to acknowledge them as theological sources. Lived experience is represented in data that the researcher subsequently interprets to systematise the presence of God in such experiences. In other words, the theologian may learn about God through the words and deeds of a community. This shows a different reality but a reality that is no less valuable than what can be read and analysed from documents on theology or tradition.

The techniques developed herein show that the participants are not mere objects of research but active subjects in the construction of knowledge. Participants present problems related to God which deserved to be addressed in a reflexive and systematic manner. Enabling tools for communities to act as agents of their own projects rather than mere receptacles of interventions from external agents is essential. Collective constructions can reach academic standards with proper support.

Fieldwork in the theological field enables wider perspectives in the pastoral aspect with different sectors of the population. In addition, it provides theology with the possibility of acknowledging the words of people as having a theological place and being a theological source from which languages and perspectives regarding the experience of God can be assessed. The articulation between research and pastoral processes allows for the analysis and systematisation of the effectiveness of the initiatives undertaken by churches in peripheral areas in such a way that the impact of the people's religious experience is clarified. This, in turn, allows researchers to assess and formulate improvement strategies.

Theological reflection regarding the role of women in Church and manliness is more necessary than ever. The research results show that women are the main actors in ecclesiastic and educational processes. This situation can be seen since the first Christian communities, which should only strengthen the commitment to redeem their place in society, culture and power and government structures. Encouraging men's involvement in ecclesiastic communities' processes is a challenge related to work opportunities and housework. Insofar as balance can be present between these aspects, the involvement of both genders in pastoral activities should probably become evident with respect to time and mood.

Ecclesiastic intervention in communitarian processes is essential to achieve political and critical thinking. The pastoral activity is also a space for discussion regarding earthly realities, enlightenment through revelation and an attempt to search for specific personal and social transformation strategies.

The school should always be the favoured space for social conscience formation, mediated by knowledge, because it allows interaction with the community as well as with those congregating in the temple to give thanks to God. Formal education is a pastoral space par excellence; the church's involvement in educational projects is crucial to strengthen the human aspect in the cultural context.

\section{The God of the peripheral areas of Medellín}

The surveys shape the communities' understanding of God which, somehow, accounts for a language typical of Christianity. The surveys were presented in a theoretical framework with which the population sample identified itself to a greater or lesser extent. The existence of God is a statement believed to be present amongst the people who participated in the survey (Alvarado Marambio 2016). This fact is not strange because Colombia and Medellín in general are considerably religious territories with vast evangelising experiences, and secularisation and secularism processes have not yet penetrated the territories in a widespread manner. The existence of God is not necessarily questioned.

God is primarily considered to be personal, spiritual and supreme (Ramos González 2016), with religion as the background that is experienced as a relationship between men and transcendence, characterised precisely by his kindness. At this point, emphasis is placed on the intimacy of humanity and its bond with God without the need for mediations, although these exist. 
The personal view of God is articulated with a Trinitarian view of transcendence (Biris 2018; Filtvedt 2017). To state that God is Father, Son and Holy Spirit summarises the teaching of the western Judeo-Christian tradition that the community also lives and feels. During the interviews, it seemed that the method of explaining the Trinitarian belief was not clear; even for theologians, this topic has remained a dogmatic assertion worthy of an in-depth study in order to be understood. People living in peripheral ecclesiastic communities identify themselves with the dogmatic formulation, although they do not know how to explain their experience in relation to such assertions.

To believe in God is an act of trust to follow him (Sarot 2016) rather than mere speculation. In the context of peripheral areas, ideas do not always have practical consequences for the communities. Therefore, trusting in God is a clearer option. People believe that, for example, he can do anything and will help transform the circumstances that have darkened humanity, the different forms of poverty, oppression and shortages. Believing means to trust against all odds that God will always do justice and, to get closer to him, strategies typical of tradition such as prayers, sacraments, a novena, rosaries, help from others and so forth are used.

The interviewed communities believe that God is, above all, a powerful father (Sarot 2016) who creates and has the ability to do whatever he wants and intervene in the world at his own discretion. Such characteristics are related to the trust people have in him because the possibilities to improve emerge because of his power and compassion.

\section{Popular theological education}

The FGs show necessary knowledge regarding ecclesiastic comprehension on the first article of Christian faith. Namely, what people believe is articulated with ecclesiastic theological speech and no edges or aspects that may divert attention of what is regularly practised are present. There is a framing within the context of Trinitarian confession and the classical characteristics of God.

This means that people's words about God are expressed in a theological, classical language that is foreign and distant to the Latin American theological languages. Although every person expresses his or her religiousness in a specific and diverse manner, generally speaking, the background is the same conception of God imparted by Catholicism.

According to the above, upon an enquiry regarding the meaning of the dogmatic assertions 'I believe in God, father, creator of heaven and earth', doubts, inaccuracies or ignorance of what this means could be noted - for example, the meaning expressed in the Bible regarding creation. In some aspects, a popular theological education is necessary to enable the articulation of God's speech as well as its understanding of both its past and present meaning and its application in a specific context.
Popular theological education means to provide tools for the communities to analyse their realities, interpret their experience of God and establish practical strategies of social transformation. Often, education in ecclesiastic communities is limited to the repetition of the contents of faith, learnt by heart or by the teaching of the catechism. However, there is no communitarian self-management process in terms of knowledge or projects that may cause an impact on the social and ecclesiastic realities.

Popular theological education processes represent a great challenge that derives from this research, to the extent that communities may be active agents of their processes, explore their own experiences with God and be able to speak about them without fear of making a mistake or being criticised. Thus, original experiences about God should be recovered to nurture the existing understanding of God while preserving the Judeo-Christian tradition.

\section{Conclusion}

The peripheral ecclesiastic communities of Medellín are diverse and have their own characteristics. These communities account for a Latin American ecclesiastic feature as well as, in general, for the universal ecclesiastic tradition, and act as the centre for women's involvement in communitarian processes. Communities nurture faith in children, who even attend school in a Christian context. Poverty, within the context of this study, is related to socioeconomic scarcity. Here, great trust in God is perceived: he can do anything and through love; he can transform personal and social realities.

The participants' words about God have a classic theological language as their background; for some participants, this is even misunderstood. The meaning of these words reveals ecclesiastic practices of catechist education that should be transmitted, which should also be addressed to self-comprehension and production from the subjects' contexts.

As the surveys were conducted by following a pre-established theoretical framework, the responses show a series of imaginaries and identification of people in relation to what they perceive to be God. In addition, the surveys are constructed in a limited fashion, meaning that the answers are partially restricted. Thus, research techniques that are more participatory in nature, such as life story-telling or substantiated theory, should be explored to enable a wider margin of movement.

The contemporary theological community faces the great challenge of building knowledge about God through the development of methodologies that allow recognising, assessing and systematising the experience of peoples regarding the deity. Furthermore, a consideration of the application of research strategies aimed at contexts' transformation is necessary, such as participatory action research. It would be appropriate to conduct studies for the 
construction of languages and the systematisation of experiences of God in contexts other than the peripheral and comparing the stories of people with different lifestyles. This would enrich theological and ecclesiastic work as well as the understanding perceived from dogma that is transmitted from generation to generation, even in other countries of the world.

\section{Acknowledgements}

We thank the participants and all those who contributed to the development of the study.

\section{Competing interests}

The authors have declared that no competing interests exist.

\section{Author's contributions}

All authors contributed equally to this work.

\section{Funding information}

This research received a specific grant from the Pontifical Bolivarian University.

\section{Data availability statement}

Data sharing is not applicable to this article as no new data were created or analysed in this study.

\section{Disclaimer}

The views and opinions expressed in this article are those of the authors and do not necessarily reflect the official policy or position of any affiliated agency of the authors.

\section{References}

Alcaldía de Medellín, 2017, Índice Multidimensional Encuesta Calidad de Vida 2011-2017, Planeación, Medellín.

Alvarado Marambio, J.T., 2016, '¿Qué es una "religión"? Tres teorías recientes', 'llu. Revista de Ciencias de las Religiones 21, 31-49. https://doi.org/10.5209/ ILUR. 53839
Biris, I., 2018, 'On the logic the Christian trinity: Co-inherence and the nesting relationships', Journal for the Study of Religions \& Ideologies 17(50), 17-29, viewed 30 September 2019, from http://search.ebscohost.com/login.aspx?direct

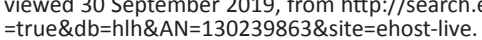

Cáceres, P., 2003, 'Análisis cualitativo de contenido: Una alternativa metodológica alcanzable', Psicoperspectivas 2(1), 53-82.

Cifuentes Gil, R., 2011, Diseño de proyectos de investigación cualitativa, Noveduc, Buenos Aires.

Comissão Teológica Internacional, 2012, Teologia hoje: Perspectivas princípios e critérios, Libreria Editrice Vaticana, Roma.

Comissão Teológica Internacional, 2014, O sensus fidei na vida da Igreja, Libreria Editrice Vaticana, Roma.

Conselho Episcopal Latino-Americano, 2007, Conclusões. V Conferência Geral do Episcopado Latino-Americano e do Caribe, O Autor, Aparecida.

De Lecaros, V.C.G., 2017, '¿'Dios castigador, Dios juez o Dios amado? Imágenes de Dios en medios católicos y pentecostales peruanos', Horizonte 15(46), 571-594. https://doi.org/10.5752/P.2175-5841.2017v15n46p571

Filtvedt, O.J., 2017, 'The transcendence and visibility of the Father in the Gospel of John', Zeitschrift für die neutestamentliche Wissenschaft 108(1), 90-118. https:// doi.org/10.1515/znw-2017-0003

Francis, P., 2015a, Ludato Si', Libreria E, Roma.

Francis, P., 2015b, Misericordiae vultus, Libreria E, Roma.

Gadamer, H.-G., 2004, Verdad y método, Sígueme, Salamanca.

Guber, R., 2011, La etnografía: Método, campo y reflexividad, Siglo Veinte, Buenos Aires.

Gutiérrez, G., 2000, Teologia da libertação. Perspectivas, Edições Loyola, São Paulo.

Heidegger, M., 2009, Ser y tiempo, Trottam, Madrid.

Jensen, E., 2018, 'Hell and the image of God in the spiritual exercise', Way 57(3), 91-102, viewed 30 September 2019, from http://search ebscohost.com/login.asp $x$ ?direct=true\&db=a9h\&AN=130667933\&site=ehost-live.

Lane, A.N.S., 2018, 'The Nicene creed: A round table discussion', Evangelical Quarterly 89(2), 99-114, viewed 30 September 2019, from http://search.ebscohost.com/ login.aspx?direct=true\&db=a9h\&AN=129405895\&site=ehost-live.

Luciani, R., 2017, 'La opción por los pobres desde una Iglesia pobre y para los pobres', Medellín XLIII(168), 347-373.

Müller, G., 1998, Dogmática, Herder, España.

Orofino, F. \& Mesters, C., 2007, 'Sobre la lectura popular de la Biblia', Pasos 130, 16-26.

Parra, A., 2003, Textos, contextos y pretextos, Pontificia Universidad Javeriana, Bogotá.

Rahner, K., 1979, Curso fundamental sobre la fe, Herder, Barcelona.

Ramos, C.A., 2015, 'Los paradigmas de la investigación científica', Av.psicol 23(1), 9-17. https://doi.org/10.33539/avpsicol.2015.v23n1.167

Ramos González, A., 2016, 'Ateísmo y espiritualidad', 'Ilu. Revista de Ciencias de las Religiones 21, 165-183. https://doi.org/10.5209/ILUR.53851

Sarot, M. 2016, 'Believing in God the Father: Interpreting a phrase from the Apostle's Creed', Theological Studies 72(4), 1-4. https://doi.org/10.4102/hts.v72i4.3287

Turpe Chaparro, J.R., 2017, 'Las presuposiciones filosóficas de la investigación teológica (bíblica y sistemática)', Revista de Investigación Apuntes Universitario 7(1), 166-178. https://doi.org/10.17162/au.v7i1.158

Uwineza, M., 2018, 'The human person is the question to which God is the answer: Humanity in the Theology of Karl Rahner', Way 57(2), 75-89, viewed 30 September 2019, from http://search.ebscohost.com/login.aspx?direct=true\&db=a9h\&AN=1 29526043\&site=ehost-live.

Waldenfels, H., 1994, Teología fundamental contextual, Sígueme, Salamanca.

Younger, P.L., 2018, 'Way beyond all science: A scientist's perspective on knowing God', Way 57(2), 7-16, viewed 30 September 2019, from http://search.ebscohost. com/login.aspx?direct=true\&db=a9h\&AN=129526036\&site=ehost-live. 